\title{
Intubating conditions and
} neuromuscular block after

Nileshkumar Patel MD, Nandan Kamath, Charles E Smith MD FRCPC, Alfred C Pinchak MD, PE PHD, Joan $H$ Hagen BA divided dose mivacurium or single dose rocuronium

\begin{abstract}
Purpose: To evaluate the tracheal intubating conditions and neuromuscular blocking characteristics of divided dose mivacurium or single dose rocuronium.

Methods: Thirty-two patients undergoing elective surgery were studied. Anaesthesia was with propofol 2 $\mathrm{mg} \cdot \mathrm{kg}^{-1}$, followed by an infusion of $150 \mu \mathrm{g} \cdot \mathrm{kg}^{-1} \cdot \mathrm{min}^{-1}$. Patients were randomized to receive either mivacurium$0.15 \mathrm{mg} \cdot \mathrm{kg}^{+}$followed $30 \mathrm{sec}$ later by $0.1 \mathrm{mg} \cdot \mathrm{kg}^{\prime}$. or rocuronium- $0.9 \mathrm{mg} \cdot \mathrm{kg}^{\prime}$. followed $30 \mathrm{sec}$ later by placebo. Tracheal intubating conditions were assessed $90 \mathrm{sec}$ after the initial dose of relaxant by an anaesthetist who was unaware of patient group. The electromyographic (EMG) response of the first dorsal interosseus muscle to ulnar nerve train-of-four was measured.
\end{abstract}

Results: Succesfful tracheal intubation was performed in all patients after both mivacurium and rocuronium. Intubating conditions (jaw relaxation, open visible vocal cords) were judged to be good-excellent in all but one patient before insertion of the tracheal tube. However, patients receiving mivacurium were more likely to experience coughing and bucking after tracheal tube insertion (10/16 patients) than those receiving rocuronium (3/16 patients, $P<0.05$ ). No patient in the rocuronium group experienced moderately vigorous coughing and bucking after insertion of the tracheal tube vs six patients in the mivacurium group $(P<0.05)$. Time to 10 and $25 \%$ recovery of neuromuscular function was faster $(P<0.05)$ after divided dose mivacurium $(20 \pm 1$ and $23 \pm 1$ min, respectively) than after rocuronium ( $45 \pm 5$ and $57 \pm 8 \mathrm{~min}$, respectively).

Conclusion: The results suggest that. during conditions of the study, divided dose mivacurium is not recommended for a 90-sec tracheal intubation in patients where moderate coughing and bucking is deemed unacceptable.

Objectif : Évaluer les conditions de l'intubation de la trachée et les caractéristiques du bloc neuromusculaire au mivacurium à dose fractionnée et au rocuronium à dose unique.

Méthodes : Cette étude réunissait 22 patients programmés pour une chirurgie non urgente. Lanesthésie était réalisée avec du propofol $2 \mathrm{mg} \cdot \mathrm{kg}^{-1}$, suivi d'une perfusion de $150 \mu \mathrm{g} \cdot \mathrm{kg}^{\prime} \cdot \mathrm{min}^{-1}$. Les patients recevaient aléatoirement soit du mivacurium $0.15 \mathrm{mg} \cdot \mathrm{kg}^{-1}$ suivi 30 sec plus tard par $0,1 \mathrm{mg} \cdot \mathrm{kg}^{-1}$, soit du rocuronium $0,9 \mathrm{mg} \cdot \mathrm{kg}^{-1}$, suivi $30 \mathrm{sec}$ plus tard d'un placebo. Les conditions d'intubation de la trachée étaient évaluées $90 \mathrm{sec}$ après la dose initiale de myorelaxant par un anesthésiste ignorant le groupe auquel le patient appartenait. La réponse électromyographique (EMG) à la stimulation au train-de-quatre (TOF) du premier muscle interosseux dorsal était mesurée.

Résultats : Lintubation de la trachée a été réussie chez tous les patients des deux groupes. Les conditions d'intubation (relaxation de la máchoire, visualisation de cordes vocales béantes) avant l'insertion de la canule trachéale étaient jugées de bonnes à excellentes chez tous les patients à l'exception d'un seul. Cependant, les patients sous mivacurium étaient plus sujets à la toux et au cabrage après l'insertion de la canule (10/16 patients) que ceux qui avaient reçu le rocuronium. $(3 / 16$ patients, $P<0,05)$. Aucun des patients du groupe rocuronium n'a présenté de toux et de cabrage notoires après l'insertion de la canule comparativement à six patients du groupe mivacurium $(P<0.05)$. Le temps de récupération à $10 \%$ et $25 \%$ de la fonction neuromusculaire était plus rapide $(P<0,05)$ après le mivacurium d̀ dose fractionnée (respectivement $20 \pm 1 \mathrm{~min}$ et $23 \pm 1 \mathrm{~min}$ ) qu'après le rocuronium (respectivement $45 \pm 5$ et $57 \pm 8 \mathrm{~min}$ ).

Conclusion : Ces résultats suggèrent que dans les conditions de l'étude, le mivacurium à dose fractionnée riest pas recommandé après 90 sec pour une intubation de la trachée chez des patients chez qui une toux ou un cabrage d'intensité modérée sont jugés inacceptables.

From the Department of Anesthesiology, Case Western Reserve University, MetroHealth Campus, 2500 MetroHealth Drive, Cleveland, Ohio 44109

Supported by the MetroHealth Foundation (N. Kamath). Presented in part at the Canadian Anaesthetists Society Annual Meeting, June, 1995 and the Ohio Society of Anesthesiologists Annual Meeting, September 9, 1995.

Burroughs Wellcome Inc. donated the mivacurium, and Organon Inc. donated the rocuronium.

Address correspondence to: Dr C.E. Smich Email-ces4@po.cwru.edu.

Accepted for publication September 7, 1996. 


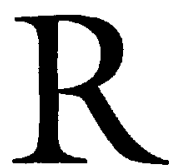

OCURONIUM is a nondepolarizing, steroidal muscle relaxant with an $\mathrm{ED}_{95}$ of $0.3 \mathrm{mg} \cdot \mathrm{kg}^{-1}$, intermediate duration of action, no histamine release, and a rapid onset time. ${ }^{1,2}$ The rapid onset associated with rocuronium has been attributed to this drug's lower poten$\mathrm{Cy}^{3}{ }^{3}$ which may allow more molecules to access the effector sites during the first few circulation times. Mivacurium is a nondepolarizing relaxant of the benzylisoquinoline type, with an $\mathrm{ED}_{95}$ of $0.06 \mathrm{mg} \cdot \mathrm{kg}^{-1}$, short duration of action and mild histamine releasing properties. ${ }^{4}$ The short duration of mivacurium is due to rapid hydrolysis by plasma cholinesterase. ${ }^{4}$

Good to excellent tracheal intubating conditions have been reported within $60 \mathrm{sec}$ following rocuronium, $0.6-1.2 \mathrm{mg} \cdot \mathrm{kg}^{-1}\left(2-4 \times \mathrm{ED}_{95}\right),{ }^{2}$ and within 120 $\mathrm{sec}$ following mivacurium, $0.15-0.20 \mathrm{mg} \cdot \mathrm{kg}^{-1}(2-2.5$ $\left.\times \mathrm{ED}_{95}\right)$, in anaesthetized patients. ${ }^{5,6}$ Recently, Ali et al. have shown that divided dose mivacurium, 0.15 followed by $0.1 \mathrm{mg} \cdot \mathrm{kg}^{-1}$, compared favourably with succinylcholine $1.5 \mathrm{mg} \cdot \mathrm{kg}^{-1}$ preceded by $\mathrm{d}$-tubocurarine, $0.05 \mathrm{~g} \cdot \mathrm{kg}^{-1}$ in terms of tracheal intubating conditions. ${ }^{7}$ Using this mivacurium intubating paradigm, they reported successful tracheal intubation $90 \mathrm{sec}$ after the initial dose of mivacurium in $24 / 25$ patients, with an intubating score of good or excellent in $23 / 25$ patients. $^{7}$ There was, however, a $43 \%$ incidence of coughing after insertion of the endotracheal tube. ${ }^{7}$ The purpose of this randomized, double blind study was to compare the tracheal intubating conditions and neuromuscular blocking characteristics associated with divided dose mivacurium and single dose rocuronium in anaesthetized patients.

\section{Methods}

The protocol was approved by the Institutional Review Board. All patients gave written informed consent. Thirty-two adult ASA physical status I-III patients undergoing elective surgery requiring general anaesthesia, tracheal intubation, and neuromuscular blockade were randomly assigned to receive mivacurium or rocuronium. Randomization was with a table of random numbers. Exclusion criteria were suspected difficulty with mask ventilation (i.e., obesity, thick beard, massive jaw, facial burns/grafts) or difficult direct laryngoscopy (i.e., disproportionately increased size of base of tongue relative to pharynx size, decreased mandibular space, and decreased extent and mobility of airway joints). Additional exclusion criteria were therapy with drugs known to interfere with neuromuscular transmission, liver disease, renal disease, and plasma cholinesterase deficiency. No premedication was used. Monitors consisted of ECG, noninva- sive blood pressure cuff, pulse oximeter, end-tidal $\mathrm{CO}_{2}$, oesophageal stethoscope, and temperature. Anaesthesia was induced with 1-2 mg midazolam, 50-100 $\mathrm{\mu g}$ fentanyl, $20 \mathrm{mg}$ lidocaine, and $2 \mathrm{mg} \cdot \mathrm{kg}^{-1}$ propofol, and maintained with $150 \mu \mathrm{g} \cdot \mathrm{kg}^{-1} \cdot \mathrm{min}^{-1}$ propofol prior to intubation. The patients' lungs were ventilated with $100 \% \mathrm{O}_{2}$ to maintain end- tidal $\mathrm{CO}_{2}$ between $30-35 \mathrm{mmHg}$. Anaesthesia was maintained with isoflurane and $\mathrm{N}_{2} \mathrm{O}$ after intubation.

The hand, wrist and forearm were immobilized in a splint. Following induction of anaesthesia, the evoked compound electromyographic (EMG) response of the first dorsal interosseus muscle to ulnar nerve train-offour (TOF) supramaximal stimulation was evaluated at $10 \mathrm{sec}$ intervals with the Relaxograph Monitor (Model NMT-100, Datex Instrumentarium Corp., Helsinki, Finland). The EMG amplitude was measured three milliseconds after the stimulation pulse, and the measuring window width was $15 \mathrm{msec}$. After a stable EMG response was obtained, patients in the mivacurium group received divided doses of this agent, 0.15 $\mathrm{mg} \cdot \mathrm{kg}^{-1}$, followed by $0.1 \mathrm{mg} \cdot \mathrm{kg}^{-1}, 30 \mathrm{sec}$ later (total dose approximately $3 \times \mathrm{ED}_{95}$ ). Patients in the rocuronium group received a single $3 \times \mathrm{ED}_{95}$ dose of this drug, $0.9 \mathrm{mg} \cdot \mathrm{kg}^{-1}$, followed by $0.9 \%$ saline (placebo). Study relaxants were prepared and injected into a free running IV by a physician not involved in grading laryngoscopy and intubation. Direct laryngoscopy by an experienced intubator, unaware of the TOF response or of the relaxant, was started $90 \mathrm{sec}$ after the initial dose of relaxant. Orotracheal intubation was performed immediately after visualization of the vocal cords. A\# 3 or \#4 Macintosh laryngoscope blade was used. A cuffed $7.0 \mathrm{~mm}$ I.D. tracheal tube was used in female patients and a cuffed $8.0 \mathrm{~mm} \mathrm{I.D.} \mathrm{in} \mathrm{males}$ (Mallinckrodt Medical Inc, St Louis, MO). Intubating conditions were graded using standardized criteria. ${ }^{8}$ Jaw relaxation prior to laryngoscopy was classified as excellent if the jaw was completely mobile, good if the jaw was partly mobile, or poor if the jaw was immobile. Vocal cords at intubation were classified as visible and open, visible but moving, visible but closed, or not visible. Presence of coughing, bucking, or movement after insertion of the tracheal tube was evaluated as none, mild- 1 or 2 weak coughs, moderate- $>2$ coughs and moderately vigorous coughing and bucking, or severe- purposeful movement, very vigorous coughing and bucking. Duration of intubation and number of intubation attempts were recorded.

The following data were measured: maximal first EMG $\left(T_{1}\right)$ depression $\left(T_{1} /\right.$ control $\left.\times 100\right)$ achieved after relaxant administration, time to achieve $80 \%$ and maximal depression of $T_{1}, T_{1} 90 \mathrm{sec}$ after the initial dose of 
relaxant, and time to $10 \%, 25 \%$ and $75 \%$ spontaneous recovery of $T_{1}$. Blood pressure and heart rate were recorded at baseline prior to induction of anaesthesia, 5 and $10 \mathrm{~min}$ after intubation, and at the end of surgery.

Data are reported as mean values \pm standard errors cf the mean (SEM). Demographic and neuromuscular data were compared between groups using Student's t test. Haemodynamic data were compared using analysis of variance with Tukey's test. Intubating conditions were compared using the Cochran-Mantel- Haenszel statistic. A $P$ value $<0.05$ was considered significant.

\section{Results}

The groups were similar in age, weight, height, duration of surgery and time spent in the recovery room (Table I). There were more women in the mivacurium than in the rocuronium group (Table 1). There were no differences in blood pressure or heart rate between groups (Table II). All patients were classified as Mallampati class I and there were no difficulties in visualizing the vocal cords in any patient. All tracheas

TABLE I Demographic data in patients receiving divided dose mivacurium, total dose $0.25 \mathrm{mg} \cdot \mathrm{kg}^{-1}$, or single dose rocuronium, $0.9 \mathrm{mg} \cdot \mathrm{kg}^{-1}$.

\begin{tabular}{lll}
\hline & Mivacurium & Rocuronium \\
\hline Age (yr) & $33 \pm 2$ & $36 \pm 3$ \\
Weight $(\mathrm{kg})$ & $73 \pm 4$ & $72 \pm 6$ \\
Height $(\mathrm{cm})$ & $160 \pm 2$ & $169 \pm 3$ \\
Sex $(\mathrm{M} / \mathrm{F})$ & $1 / 15^{*}$ & $4 / 12$ \\
Duration of Surgery (min) & $76 \pm 15$ & $99 \pm 18$ \\
Duration of Recovery (min) & $113 \pm 11$ & $94 \pm 10$ \\
\hline
\end{tabular}

Mean \pm SEM. $" P<0.05$ ps other relaxant

TABLE II Haemodynamic data in patients receiving divided dose mivacurium, total dose $0.25 \mathrm{mg} \cdot \mathrm{kg}^{-1}$, or single dose rocuronium, $0.9 \mathrm{mg} \cdot \mathrm{kg}^{-1}$. Direct laryngoscopy and intubation was 90 sec after the initial dose of relaxant.

\begin{tabular}{|c|c|c|c|c|}
\hline & \multicolumn{2}{|c|}{ After Intubation } & \multirow[b]{2}{*}{$10 \min$} & \multirow[b]{2}{*}{$\begin{array}{l}\text { End of } \\
\text { Surgery }\end{array}$} \\
\hline & Baseline & $5 \min$ & & \\
\hline \multicolumn{5}{|c|}{ Systolic Blood Pressure (mmHg) } \\
\hline Mivacurium & $121 \pm 5$ & $117 \pm 3$ & $105 \pm 4$ & $134 \pm 5$ \\
\hline Rocuronium & $126 \pm 6$ & $118 \pm 5$ & $107 \pm 3$ & $132 \pm 5$ \\
\hline \multicolumn{5}{|c|}{ Mean Arterial Pressure (mm Hg) } \\
\hline Mivacurium & $88 \pm 4$ & $87 \pm 3$ & $79 \pm 4$ & $101 \pm 3$ \\
\hline Rocuronium & $95 \pm 4$ & $88 \pm 4$ & $81 \pm 3$ & $103 \pm 4$ \\
\hline \multicolumn{5}{|c|}{ Diastolic Blood Pressure (mmHg) } \\
\hline Mivacurium & $72 \pm 4$ & $72 \pm 3$ & $65 \pm 4$ & $84 \pm 3$ \\
\hline Rocuronium & $80 \pm 4$ & $74 \pm 4$ & $67 \pm 3$ & $88 \pm 4$ \\
\hline \multicolumn{5}{|c|}{ Heart Rate (beats per minute) } \\
\hline Mivacurium & $76 \pm 3$ & $93 \pm 5$ & $84 \pm 4$ & $86 \pm 3$ \\
\hline Rocuronium & $81 \pm 3$ & $96 \pm 4$ & $94 \pm 5$ & $89 \pm 4$ \\
\hline
\end{tabular}

Mean \pm SEM were successfully intubated on the first attempt within 15 sec of beginning direct laryngoscopy. The $T_{1}$ at intubation was $52 \pm 5 \%$ with mivacurium and $8 \pm 3 \%$ with rocuronium $(P<0.05)$. Although all patients developed $100 \%$ neuromuscular blockade, compared with divided dose mivacurium, rocuronium, 0.9 $\mathrm{mg} \cdot \mathrm{kg}^{-1}$, was associated with faster times to $80 \%$ and $100 \% \mathrm{~T}_{1}$ block $(P<0.05$, Table III). Compared with rocuronium, patients receiving mivacurium were more likely to experience moderate coughing and bucking after tracheal tube insertion, $P<0.05$, Table IV). Spontancous recovery to $10 \%$ and $25 \% \mathrm{~T}_{1}$ was longer after rocuronium than after mivacurium $(P<0.05$, Table III). Five patients (31\%) in the mivacurium group required reversal of neuromuscular blockade compared with 13 patients $(81 \%)$ in the rocuronium group $(P<0.05)$. Three patients in the mivacurium group (two of whom had no reversal agents) and one patient in the rocuronium group required treatment for post- operative vomiting.

TABLE III Onset and recovery of neuromuscular block in patients receiving divided dose mivacurium, total dose 0.25 $\mathrm{mg} \cdot \mathrm{kg}^{-1}$, or single dose rocuronium, $0.9 \mathrm{mg} \cdot \mathrm{kg}^{-1}$.

\begin{tabular}{lll}
\hline & Mivacurium & Rocuronium \\
\hline $\mathrm{T}_{1}$ at Intubation, \% & $52 \pm 5^{*}$ & $8 \pm 3$ \\
Time to $80 \% \mathrm{~T}_{1}$ block $(\mathrm{sec})$ & $116 \pm 3^{\star}$ & $61 \pm 6$ \\
Time to $100 \% \mathrm{~T}_{1}$ block $(\mathrm{sec})$ & $183 \pm 5^{*}$ & $108 \pm 9$ \\
Time to $10 \%$ recovery $\mathrm{T}_{1}(\mathrm{~min})$ & $20 \pm 1^{*}$ & $45 \pm 5$ \\
Time to $25 \%$ recovery $\mathrm{T}_{1}(\mathrm{~min})$ & $23 \pm 1^{*}$ & $57 \pm 8$ \\
Recovery Index (min) & $8 \pm 1$ & $17 \pm 10$ \\
\hline
\end{tabular}

Mean \pm SEM. ${ }^{\star} P<0.05$ ps other relaxant, Student's t test

TABLE IV Tracheal intubating conditions in patients receiving divided dose mivacurium, total dose $0.25 \mathrm{mg} . \mathrm{kg}^{-1}$, or single dose rocuronium, $0.9 \mathrm{mg} \cdot \mathrm{kg}^{-1}$.

\begin{tabular}{|c|c|c|}
\hline & Mivacurium & Rocusonium \\
\hline \multicolumn{3}{|l|}{ Jaw Relaxation } \\
\hline Excellent, completely mobile & $14(88 \%)$ & $14(88 \%)$ \\
\hline Good, partly mobile & $1(6 \%)$ & $2(12 \%)$ \\
\hline Poor, immobile & $1(6 \%)$ & 0 \\
\hline \multicolumn{3}{|l|}{ Vocal Cords } \\
\hline Excellent, visible and open & $16(100 \%)$ & $16(100 \%)$ \\
\hline Visible but moving & 0 & 0 \\
\hline Visible but closed & 0 & 0 \\
\hline \multicolumn{3}{|l|}{ Cough/Buck response * } \\
\hline None & $6(37 \%)$ & $13(81 \%)$ \\
\hline $\begin{array}{l}\text { Slight, } 1 \text { or } 2 \text { weak coughs } \\
\text { Moderate }>2 \text { coughs }\end{array}$ & $4(25 \%)$ & $3(19 \%)$ \\
\hline moderately vigorous & $6(37 \%)$ & 0 \\
\hline $\begin{array}{l}\text { Severe, very vigorous response, } \\
\text { purposeful movement }\end{array}$ & 0 & 0 \\
\hline
\end{tabular}

Data are number (\%) of patients.

* $P<0.05$ vs other relaxant, Cochran Mantel-Haenszel test. 


\section{Discussion}

The study demonstrated that successful tracheal intubation could be accomplished in all patients with both divided dose mivacurium and single dose rocuronium. Intubating conditions, as assessed by good jaw relaxation and open visible vocal cords, were judged to be good-excellent in all but one patient prior to insertion of the tracheal tube. However, the use of mivacurium was associated with a $37 \%$ incidence of moderate coughing and bucking following intubation and, in one patient (mivacurium group), the jaw was immobile prior to laryngoscopy.

It is recognized that the determination of tracheal intubating conditions is dependent upon the skills and experience of the intubator, the anatomy of the patient, and upon subjective criteria. In the study, an experienced anaesthetist, blinded to the relaxant, assessed the intubating conditions at a predetermined time interval using a standardized scoring system. It is unlikely that bias from different intubators could have accounted for the differences in coughing and bucking after tube insertion observed in the study. This is because the cough buck response represented the most objective of the criteria evaluated. This response was not subtle, but obvious and apparent, and most likely represented incomplete paralysis of the muscles of the diaphragm, larynx, and/or abdominal wall.

The onset time of nondepolarizing muscle relaxants in the central airway musculature of the larynx, jaw and diaphragm is dependent on the presence of a critical number of drug molecules at the neuromuscular junction. ${ }^{9}$ When large doses of relaxants are given $(\geq 3 \times$ $\mathrm{ED}_{95}$ ), as in the present study, it is anticipated that optimal intubating conditions develop before loss of TOF response at the hand because neuromuscular blockade in the central airway musculature shows more rapid kinetics and dynamics than in the hand. ${ }^{10-12}$

With divided dose mivacurium, $T_{1}$ at intubation was about $50 \%$ of control, compared with $8 \%$ of control after an equipotent dose of rocuronium. It is possible that the waiting period of $90 \mathrm{sec}$ after the initial dose of mivacurium, or $60 \mathrm{sec}$ after the second dose of mivacurium, was insufficient to allow development of full neuromuscular blockade at the resistant muscles. The $90 \mathrm{sec}$ time interval between initial study drug and laryngoscopy/intubation was chosen because it has been shown for mivacurium that the period of laryngeal paralysis may be as short as two to four minutes, and if one waits for complete block at the hand muscles, neuromuscular block at the larynx may have dissipated. Plaud $e t$ al. evaluated the onset time and degree of neuromuscular block and the muscles of the adductor pollicis produced by two doses of mivacurium, 0.07 and $0.14 \mathrm{mg} \cdot \mathrm{kg}^{-1}{ }^{13}$ They found that with both doses of mivacurium, neuromuscular blockade had a faster onset, was less intense and recovered more rapidly at the vocal cords than at the thumb. ${ }^{13}$ It should be noted that complete block of the vocal cords did not occur in their study, and that maximum block at the laryngeal adductor muscles developed $133 \mathrm{sec}$ after administration of mivacurium, $0.14 \mathrm{~g} \cdot \mathrm{kg}^{-1} .{ }^{13}$ Thus, it is possible that a waiting time of about $130 \mathrm{sec}$, not $90 \mathrm{sec}$, is needed to insure optimal block with mivacurium.

Because of the design of the study, a waiting time of $90 \mathrm{sec}$ after the full dose of rocuronium was required prior to laryngoscopy and intubation. It is likely that the onset of good-excellent tracheal intubating conditions associated with this dose of rocuronium occurred earlier than $90 \mathrm{sec}$, as has previously been demonstrated. ${ }^{2}$

In the present study, TOF monitoring of the muscles of the hand was done. It has been suggested that monitoring of the facial nerve-orbicularis oculis muscle might be a better guide for determining onset of optimal intubating conditions. ${ }^{14}$ To test this hypothesis, Sayson and Mongan randomized patients to undergo tracheal intubation at either maximal depression of the orbicularis oculi or at maximal depression of the adductor pollicis after mivacurium, $0.15 \mathrm{mg} \cdot \mathrm{kg}^{-1}{ }^{15}$ They reported that despite $100 \%$ orbicularis oculi blockade, which occurred on average $134 \mathrm{sec}$ after the dose of mivacurium, 7 of 10 patients showed diaphragmatic activity, and one had purposeful movement. ${ }^{15}$ Thus, monitoring of the facial nerve-orbicularis oculis muscle may not be particularly useful to predict onset of tracheal intubating conditions following administration of mivacurium.

It has been suggested that an induction dose of propofol, $2.5 \mathrm{mg} \cdot \mathrm{kg}^{-1}$, provides adequate conditions for direct laryngoscopy and tracheal intubation, thereby obviating the need for neuromuscular blocking agents. Indeed, Davidson \& Gillespie showed that intubating conditions were acceptable in $14 / 15$ patients $(93 \%)$ receiving propofol, $2.5 \mathrm{mg} \cdot \mathrm{kg}^{-1}$, alfentanil, $20 \mathrm{~g} \cdot \mathrm{kg}^{-1}$, and lidocaine, $1 \mathrm{mg} \cdot \mathrm{kg}^{-1} \cdot{ }^{16}$ However, among these 14 patients, four experienced coughing, two had moving vocal cords, one had closed vocal cords, and two had slight difficulty with laryngoscopy. ${ }^{16}$ In a similar study, Mulholland \& Carlisle showed that intubating conditions were good- excellent in $20 / 30$ patients $(67 \%)$ anaesthetized with propofol, $2.5 \mathrm{mg} \cdot \mathrm{kg}^{-1}$, and lidocaine, $1.5 \mathrm{mg} \cdot \mathrm{kg}^{-1}$, without relaxants. ${ }^{17}$ However, in the remaining 10 patients, two had unsatisfactory conditions and eight tracheas were unable to be intubated. Scheller et al. administered various doses of alfentanil $(30,40,50$, or 
$\left.60 \mu \mathrm{g} \cdot \mathrm{kg}^{-1}\right)$, followed by propofol $2 \mathrm{mg} \cdot \mathrm{kg}^{-1}$ to patients premedicated with midazolam. ${ }^{8}$ They found that although tracheal intubation could be accomplished in these patients without the use of relaxants, $30 / 60$ patients had some degree of coughing. Of these 30 patients, five had persistent coughing after intubation and one had purposeful movement. ${ }^{8}$ Only with the higher doses of alfentanil, $50-60 \mu \mathrm{g} \cdot \mathrm{kg}^{-1}$, were acceptable intubating conditions achieved. Thus, although it is possible to intubate patients' tracheas successfully without the use of relaxants, it is unlikely that the administration of iv anaesthetics can achieve excellent intubating conditions in all patients.

In conclusion, the results of the present study demonstrated that the use of mivacurium is associated with a high incidence of moderate coughing and bucking after intubation - a response that is rarely seen with rocuronium. This movement and moderate coughing and bucking may be particularly undesirable in patients with elevated intracranial or intraocular pressure, and in patients with unstable cervical spines. The study confirmed that duration of action of a $3 \times \mathrm{ED}_{95}$ dose of mivacurium was relatively short, with a time to $10 \%$ spontaneous $T_{1}$ recovery of $19 \mathrm{~min}$, to $25 \% \mathrm{~T}_{1}$ recovery of $23 \mathrm{~min}$, and a recovery index of eight minutes. This short recovery time of mivacurium is particularly useful in surgeries where the spontaneous return of neuromuscular function, without the use of reversal agents, is desirable.

\section{Acknowledgment}

The authors would like to thank Fran Hall for her secretarial support.

\section{References}

1 Levy JH, Davis GK, Duggan J, Szlam F. Determination of the hemodynamics and histamine release of rocuronium (ORG 9426) when administered in increased doses under $\mathrm{N}_{2} \mathrm{O} / \mathrm{O}_{2}$ - sufentanil anesthesia. Anesth Analg 1994; 78: 318-21.

2 Magorian T, Flannery KB, Miller RD. Comparison of rocuronium, succinylcholine, and vecuronium for rapid-sequence induction of anesthesia in adult patients. Anesthesiology 1993; 79: 913-8.

3 Law Min JC, Bekavec I, Glavinovic MI, Donati F, Bevan $D R$. Iontophoretic study of speed of action of various muscle relaxants. Anesthesiology 1992; 77: 351-6.

4 Saparese J], Ali HH, Basta SJ, et al. The clinical neuromuscular pharmacology of mivacurium chloride (BW BI090U). A short -acting nondepolarizing ester neuromuscular blocking drug. Anesthesiology 1988; 68: 723-32.
5 Wrigley SR, Jones RM, Harrop-Griffiths AW, Platt $M W$. Mivacurium chloride: a study to evaluate its use during propofol- nitrous oxide anaesthesia. Anaesthesia 1992; 47: 653-7.

6 Goldhill DR, Whitehead JP, Emmott RS, Griffith $A P$, Bracey BJ, Flynn PJ. Neuromuscular and clinical effects of mivacurium chloride in healthy adult patients during nitrous oxide- enflurane anaesthesia. $\mathrm{Br} J$ Anaesth 1991; 67: 289-95.

7 Ali HH, Lien CA, Witkowski T, et al. Efficacy and safety of divided dose administration of mivacurium for a 90-second tracheal intubation. J Clin Anesth 1996; 8: 276-81.

8 Scheller MS, Zornow MH, Saidman LJ. Tracheal intubation without the use of muscle relaxants: a technique using propofol and varying doses of alfentanil. Anesth Analg 1992; 75: 788-93.

9 Donati F, Meistelman C. A kinetic-dynamic model to explain the relationship between high potency and slow onset time for neuromuscular blocking drugs. J Pharmacokinet Biopharm 1991; 19: 537-52.

10 Cantineau JP, Porte $F$, d'Honneur $G$, Duvaldestin $P$. Neuromuscular effects of rocuronium on the diaphragm and adductor pollicis muscles in anesthetized parients. Anesthesiology 1994; 81: 585-90.

11 Meistelman C, Plaud B, Donati F. Rocuronium (ORG 9426) neuromuscular blockade at the adductor muscles of the larynx and adductor pollicis in humans. Can J Anaesth 1992; 39: 665-9.

12 Wright PMC, Caldwell JE, Miller RD. Onset and duration of rocuronium and succinylcholine at the adductor pollicis and laryngeal adductor muscles in anesthetized humans. Anesthesiology 1994; 81: 1110-5.

13 Plaud B, Debaene B Lequeau F, Meistelman C, Donati $F$. Mivacurium neuromuscular block at the adductor muscles of the larynx and adductor pollicis in humans. Anesthesiology 1996; 85: 77-81.

14 Debaene B, Beaussier M, Meistelman C, Donati $F$, Lienhart A. Monitoring the onset of neuromuscular block at the orbicularis oculi can predict good intubating conditions during atracurium- induced neuromuscular block. Anesth Analg 1995; 80: 360-3.

15 Sayson SC, Mongan PD. Onset of action of mivacurium chloride. A comparison of neuromuscular blockade monitoring at the adductor pollicis and the orbicularis oculi. Anesthesiology 1994; 81: 35-42.

16 Davidson JAH, Gillespie JA. Tracheal intubation after induction of anaesthesia with propofol, alfentanil and i.v. lignocaine. Br J Anaesth 1993; 70: 163-6.

17 Mulbolland D, Carlisle RJT. Intubation with propofol augmented with intravenous lignocaine. Anaesthesia 1991; 46: 312-3. 